\title{
Applying the Four-Capital Model to the Assessment of Regional Development in the Lubuskie Region of Poland
}

\author{
Grzegorz Gorzelak*, Karol Olejniczak, Adam Płoszaj and Maciej Smętkowski \\ Center For European Regional and Local Studies (EUROREG), Warsaw University, Poland
}

\begin{abstract}
This paper is part of the Special Issue of European Environment devoted to the outputs of the EU SRDTOOLS project, ' which developed and applied a new model of regional sustainable development evaluation. The paper first discusses the application of the four-capital model to evaluate, in the light of an exercise carried out in collaboration with the authorities of the Lubuskie voivodship, the impact of the implementation of the regional strategy on the status of the four capitals. The findings are then contrasted with the opinions of the local government authorities and entrepreneurs. This helped identify the weaknesses of the strategy implementation and outline potential conflicts between the development of different types of capital. The same method was applied to the regional operational programme, which resulted in the formulation of recommendations for the updating of the regional development strategy and better adapting the regional operational programme to adopted goals related to sustainable regional development. Copyright (C) 2008 John Wiley \& Sons, Ltd and ERP Environment.
\end{abstract}

Received 5 October 2006; revised 30 May 2007; accepted 6 September 2007

\section{Introduction}

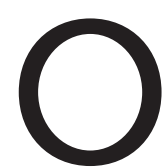

NE ADVANTAGE OF THE FOUR-CAPITAL MODEL IS THAT IT HELPS TO IDENTIFY CASES WHERE THERE is a 'contradiction' between the development of particular kinds of capital (for instance, the development of large-scale agricultural production can lead to a deterioration of the natural environment). For this reason, the paper discusses the application of the four-capital model to assess the sustainability of development and regional development strategies. This will be done using the example of the Lubuskie voivodship (a Polish region), which was chosen for this exercise for a number of reasons. First, this is a region with high environmental quality, despite a considerable degree of anthropogenic transformation of the natural environment. At the same time, the voivodship forms an

\footnotetext{
*Correspondence to: Maciej Smętkowski, Center For European Regional and Local Studies (EUROREG), Warsaw University, Poland.

E-mail: msmetkowski@uw.edu.pl

I'Methods and tools for evaluating the impact of cohesion policies on sustainable regional development' (SRDTOOLS), a Framework 6 project, DG Research Contract Number SCS8-CT-2004-502485; see http://www.srdtools.info/index.htm
} 
important part of Poland's economic system, owing to its many links with other EU countries. Whether the region will make use of its development opportunities depends on such issues as the fast development of the technical infrastructure and closing the gaps in the development levels and standards of living between the two sides of the border with Germany. In this context, the question remains open concerning the impact of the region's development capital on the remaining kinds of capital. Second, the regional authorities are distinguished for their commitment to the region's development (Lubuskie was the first to adopt a regional strategy document), a pragmatic approach and considerable openness to new programmatic methodologies and management techniques, which is proven by the best-prepared voivodship development strategy (cf. Gorzelak and Jałowiecki, 200I).

\section{The Lubuskie Voivodship - Evaluation of the Current Status of the Four Capitals}

The Lubuskie voivodship is situated in the central-western part of Poland, in the belt close to the German border (Figure I). With an area of $13984 \mathrm{~km}^{2}$, it is one of the country's smallest voivodships $(4.5 \%$ of the country's total area). Lubuskie is also one of the least populated regions of Poland (I 024 000) and has one of the lowest population density figures (73 inhabitants per $\mathrm{km}^{2}$ ). The region has two cities performing the function of regional capitals: Gorzów Wielkopolski (population I26300) is the seat of the government administration, while Zielona Góra (population II9200) is the seat of the regional self-government. Lubuskie plays an important role in Poland's economic links with the other European Union countries, with its eight large road border crossings and four railway crossings, which account for over $80 \%$ of the total cargo traffic in the central and eastern directions (towards the country's central regions and the eastern border).

In terms of GDP per capita (PLN I7 850, i.e. approx. EUR 4450), the voivodship is ranked below the national average (i.e. $87 \%$ of the average), and far below the EU average (i.e. $33 \%$ of the average). The region's economy is dominated by the service sector, with such market services as trade and repairs,

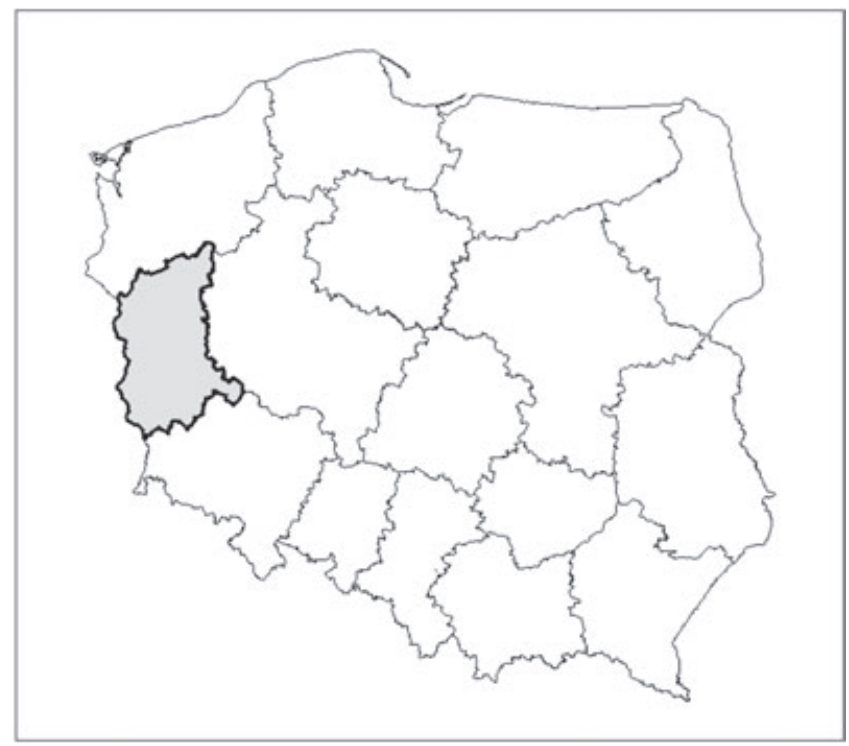

Figure 1. Location of the Lubuskie voivodship

Source: prepared by the authors. 
warehousing and communication. As regards the industrial potential, the voivodship ranks among the averagely industrialized ones. Industry, which until recently performed a core development function, underwent a deep restructuring process owing to privatization and inflow of foreign capital, mainly from Germany. The sectoral structure of industry is relatively highly diversified, with the timber, furniture and paper industries as the main sectors, based on the region's natural resources. More than half of the businesses in the region are small ones, employing up to five staff, which can be regarded as a proof of robust entrepreneurial spirit among the regional population. Most start-up companies are opened in such sectors as financial intermediation, real estate and company services, as well as health care. The average employment in a private enterprise is 2.5 staff (as compared with seven to eight in the European Union). Agriculture in the Lubuskie voivodship is characterized by the lowest share of farmland in the total area (about 40\%) and a low share of private farms, which occupy only $61 \%$ of agricultural land. In private farms, the average farmland area is $9.8 \mathrm{ha}, 50 \%$ higher than the country's average, which indirectly points to the prevalence of large-area farming. In foreign trade (both import and export), Germany is the main economic partner of the region, where nearly $70 \%$ of goods and services are directed.

The voivodship's urbanization rate is similar to the national average, with approximately $65 \%$ of residents living in cities. At the same time, Lubuskie, as opposed to the neighbouring regions and the country at large, has a relatively high percentage of pre-working-age population, and a low percentage of post-working-age population. The quality of human capital in the voivodship is relatively low, which is manifested by a low share of the population with higher education: $6.9 \%$, as compared with the national average of $8.4 \%$. What is more, the gap between the region and the other voivodships is probably increasing owing to a relatively low number of students - only 333 per to 000 population, with the national average being more than twice as high.

The Lubuskie voivodship has the highest percentage of forests in the country $-49 \%$, as compared with the national average of $29 \%$; these forests represent $7.5 \%$ of all woodland in the country. More than one-third of the voivodship's area is occupied by areas protected under law as ones with particularly valuable natural assets. There are 48 reserves with a total area of $6240 \mathrm{ha}$, seven landscape parks and numerous protected landscape areas. In addition to this, there are nearly 600 lakes in Lubuskie, most of them lying in the central part of the region, between Międzyrzecz and Świebodzin.

When we compare, in a simplified way, the state of the individual types of capital in the Lubuskie voivodship with the average condition of the four capitals' stock in Poland and the European Union (Table I), we notice that the region has a distinct deficiency of manufactured and human capital, especially when we compare it with other European Union countries. Apart from a low GDP level as compared with the EU average, the region still suffers from an acute shortage of technical and municipal infrastructure. There is a similar situation as regards social capital, the quality of which is lower than its average quality in both Poland and the EU. Conversely, the condition and the quality of the natural capital can be regarded as good or even very good as compared with the national and EU average, which is mainly due to a high share of woodland and a low population density in the region.

The position that the voivodship currently occupies is to a great extent the result of an earlier development model. It should be observed that before 1989, in the centrally planned, capital-intensive socialist economy, the development goals were mainly oriented at the production of investment assets, needed for the development of large industrial plants (in Lubuskie, chemical, plastics, paper plants and clothing factories). At the same time, fulfilling consumer needs was of secondary importance, which was manifested by the chronic shortages of basic consumer goods. Economic effectiveness was low, also with regard to rational utilization of the natural assets: excessive quantities of raw materials and energy were used, there prevailed a carefree approach to the volume of generated waste. Environmental protection investments would as a rule lose in the competition for funds with industry, particularly heavy industry. 


\begin{tabular}{|l|l|l|l|l|l|}
\hline Capitals' stock & Very poor & Poor & Average & Good & Very good \\
\hline Manufactured & & & & & \\
\hline Human & & & & & \\
\hline Social & & & & & \\
\hline Natural & & & & & \\
\hline
\end{tabular}

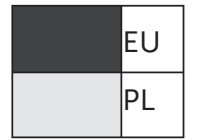

Table 1. Stock of different capitals of Lubuskie voivodship as compared with Poland and the EU Source: prepared by the authors based on statistical data analysis.

The changes begun after I989 and the building of a market economy led to increased productivity and effectiveness across the country, including reduced consumption of energy and raw materials. In consequence, the condition of the natural environment was quickly improved, mainly as a result of the collapse or restructuring of large state-owned enterprises (even though there still exist areas of ecological damage). In addition to this, abandonment of the former development model made it possible to programme the country's and the region's development in a way that takes into account the principles of sustainable development. Currently, the development goals reflect the societal needs, while aspirations and efforts to increase the productivity and effectiveness of economic activity have so far had an overall positive influence on social and natural capital.

\section{Evaluation of the Development Goals of the Lubuskie Voivodship}

The development goals are laid down in the 'Development Strategy for the Lubuskie Voivodship', a document prepared by the Marshal's Office and adopted in the form of a resolution by the Sejmik of the Lubuskie voivodship in March 2000 (Strategia Rozwoju Województwa Lubuskiego, 2000). This regional development strategy (RDS) identifies the following main development goals for the region (translated into operational objectives):

- to ensure spatial, economic and social cohesion of the region (Objective I);

- to improve the level of education of the society and increase the innovative potential of science and economy (Objective 2);

- to develop enterprise (Objective 3);

- to effectively use the natural and cultural resources (Objective 4).

The RDS was prepared on the initiative of the Lubuskie Voivodship Board. The work on the strategy was preceded by a three-day workshop for a large group of representatives of local governments, government administration and professional and academic associations. Consultations were also held among the key stakeholders with an interest in the socio-economic directions of regional development. The RDS was drafted by a team supervised by experts and incorporated the results of the consultations.

The operational objectives could be positioned using the four-capital model. To do this, an exercise was carried out with the participation of the representatives of different departments of the Marshal's Office, to define the impacts of tasks implemented as part of a given operational objective on a specific type of capital. The impacts were assessed using the following categories: negative, no impact, positive, 
very positive. In addition, a distinction was made between the potential, that is, intended impact, and the actual impact in the last four years. Furthermore, if the direction of the undertaken activities was considered undesirable or if their discontinuation could produce negative consequences for a given type of capital in the future, the category of 'warning' was introduced.

Based on an analysis of operational objectives, it can be observed that the strategy comprises - though to varying extents - all the four capitals. No operational goal was identified of which the achievement could unambiguously negatively affect any of the four capitals. According to the regional authorities, four years after the strategy was adopted, about $60 \%$ of the goals were at least partly fulfilled. Furthermore, individual operational objectives had a concurrent impact on different types of capital, which can be seen as a proof of an integrated approach to their identification (which, in turn, can be regarded as being consistent with the principles of sustainable development). In relatively few aspects, representatives of the regional authorities feared negative consequences of attaining the adopted goals. This was mainly associated with the failure to undertake the required actions at a suitable time (primarily with regard to activities related to the development of manufactured and human capital). According to the opinions voiced by the representatives of the regional authorities, one example of threats related to pursuing the adopted goals could be provided for social and natural capitals.

An evaluation of the RDS shows the objectives that were ascribed more significance at the operational level and those whose implementation had proceeded the most smoothly over the past five years. Based on the analysis, it can be concluded that the regional authorities pay most attention to economic issues, including development of manufactured capital (Table 2), which was most deficient (see Table I). It seems that the remaining objectives were subordinated to the growth of effectiveness and productivity of the economy; they are mainly aimed to ensure the development of human capital, and - although to a lesser extent - of social and natural capital. At its simplest, it can be said that in the case of the Lubuskie voivodship, where the level of economic development is low, economic growth can exert a positive influence on the improvement of the stock of the other three capitals through improving the level of the residents' education, SME development and raising pro-environmental awareness. As regards the implementation aspect, tasks related to the development of manufactured and human capital are performed most completely of all, unlike those related to social capital, whose implementation is the least advanced. In the opinion of the local authorities, the significance attached to the different objectives corresponded to the actual needs of the region. These needs, in turn, reflect the position of the voivodship in both the Polish and European contexts.

The RDS is a document prepared by the Voivodship Board, but also a product of a political process and consensus reached between the councillors - representatives of different political parties, and an effect of consultations among different political groups as well as advice of external experts.

Empirical research ${ }^{2}$ shows that the degree of familiarity with the strategy among entrepreneurs and local (gmina) authorities was rather varied. Only $15 \%$ entrepreneurs said that they were familiar with the document. On the other hand, knowledge of the strategic objectives among the representatives of local authorities was very broad (93\%). The respondents agreed that the four strategic objectives reflected the developmental needs of the voivodship. There was a difference of opinion as regards the evaluation of the extent to which these objectives were attained, while the respondents positively evaluated the implementation of the objective related to the improvement of educational attainment and innovative potential. The implementation of tasks related to the development of enterprise and effective use of the environmental assets was evaluated as mediocre (with slightly lower ratings from the entrepreneurs).

\footnotetext{
${ }^{2}$ In the third quarter of 2005 , the first questionnaire surveys were conducted among Io6 SMEs from five gminas in the Lubuskie voivodship. Also, questionnaires with a similar set of questions were sent out to the local authorities in all 83 gminas of the voivodship. 30 filled-in questionnaires were returned, which meant a response rate of approximately $36 \%$.
} 


\begin{tabular}{|l|l|l|l|l|}
\hline & Manufactured & Human & Social & Natural \\
\hline Objective 1 & & & & \\
\hline Objective 2 & & & & \\
\hline Objective 3 & & & & \\
\hline Objective 4 & & & & \\
\hline
\end{tabular}

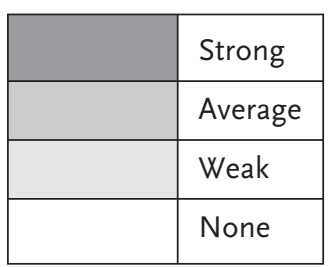

Table 2. Potential impact of strategic objectives on different capitals

Source: prepared by the authors.

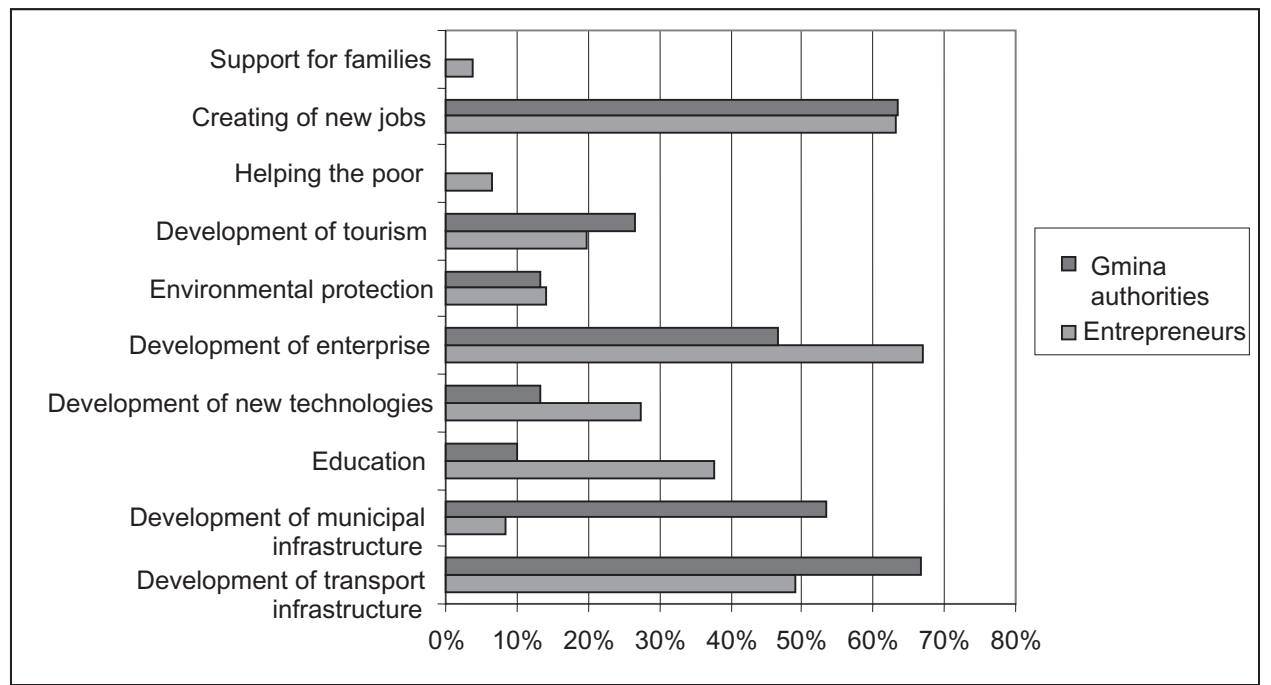

Figure 2. Key development goals according to local authorities and entrepreneurs Source: prepared by the authors.

The main point of difference was the evaluation of the increase of spatial, economic and social cohesion of the region, which - in the entrepreneurs' opinion - was achieved only to a minimal degree. On the other hand, the local authorities were of the opinion that the results achieved in this sphere were similar to those related to the development of human capital. According to the respondents, all these objectives should be continued, particularly the development of enterprise.

When given the choice to select the objectives that were of cardinal importance to the region's development, the entrepreneurs, quite naturally, opted for the development of enterprise (Figure 2). On the other hand, the representatives of the gmina authorities most frequently pointed to the development of transport infrastructure. Both groups were of the opinion that the objective related to the creation of new jobs was next in importance, followed by the development of municipal infrastructure in the opinion of the gmina authorities, with development of tourism regarded by them as more important than development of new technologies and education. On the other hand, the entrepreneurs were rather in favour of the latter two objectives. Quite surprisingly, they were more willing to pursue objectives of a social nature, related to helping the poor and their families. These objectives were not indicated by the representatives of gmina authorities, which could be a sign of their bad experiences relating to the effectiveness of public assistance and its inefficient targeting. Environmental protection as one of the major development objectives was far behind the other objectives, indicated by slightly more than Io\% of the respondents. 
At the same time, the respondents expressed a great deal of acceptance for the principles of sustainable development (cf. Parteka, I997). This was manifested by their selection of the options presented for six alternatives worded as follows (in brackets, responses of the entrepreneurs and the gmina authorities, respectively):

- high penalties should be imposed for environmental pollution, even if this meant the bankruptcy of large plants polluting the environment (73\%, 65\%);

- roads should be built more slowly and at a higher cost, to minimize adverse effect on the environment $(83 \%, 86 \%)$;

- it is better to build a longer road and at a higher cost to protect a habitat of an endangered bird species than the other way round $(89 \%, 66 \%)$;

- companies introducing new technologies should be supported, while bankruptcies of unprofitable enterprises should not be prevented (90\%, 93\%).

There was a difference of opinion regarding new investments that create new jobs but are harmful to the environment. About half of the respondents believed that in the future, thanks to new technologies, it would be possible to bring the environment back to its original state, while the other half did not agree to even a temporary deterioration of the condition of the environment. Furthermore, nearly all the respondents did not object to importing materials needed for industrial production from outside the region in the event the local reserves were exhausted.

As regards developmental barriers, the key such barrier for the respondents was the poor condition of the transport infrastructure, which was particularly strongly emphasized by the gmina authorities. Another impediment to the region's development was a low quality of life of its residents and a low level of innovation. On the other hand, the respondents did not consider environmental protection standards to be barriers to the region's development, like the level of education, which in this context was considered sufficiently high.

The entrepreneurs and gmina authorities were also asked whether they saw any contradiction between a number of different objectives or phenomena (Table 3). An analysis of their answers indicates that, in the respondents' opinion, the most glaring contradiction existed between an increase in society's

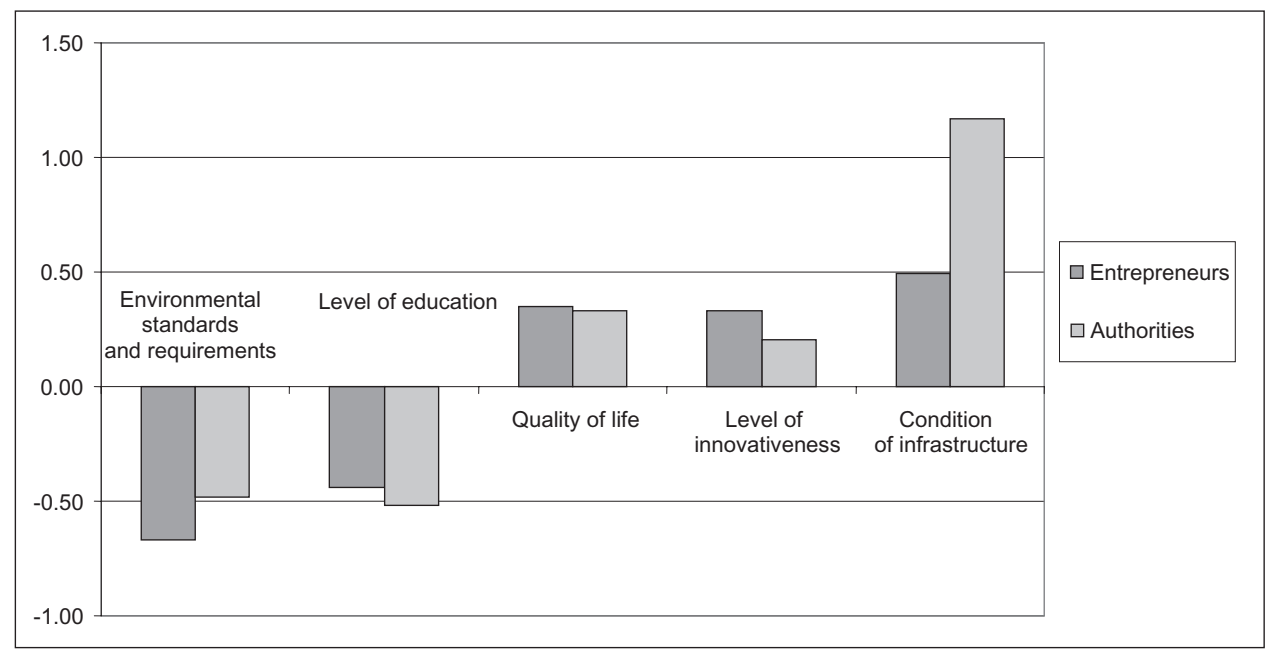

Figure 3. Factors impeding the voivodship's development (with regard to equivalent opinions, above OX axis - an impeding factor, below $O X$ axis - a given factor is not considered a barrier) (on a 1-3 scale)

Source: prepared by the authors. 


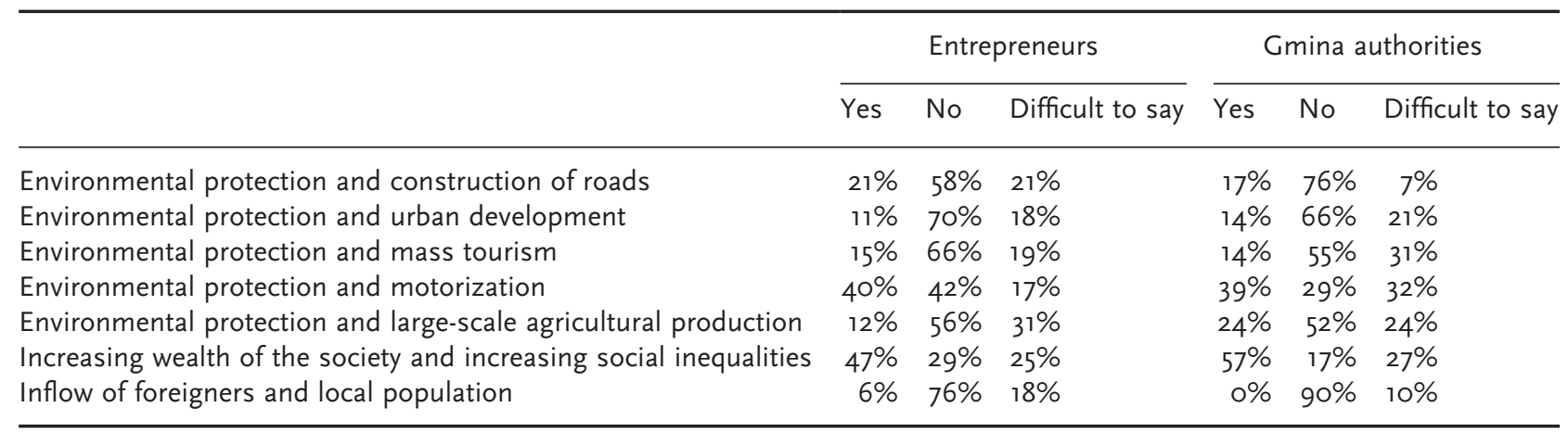

Table 3. Contradictions between pairs of objectives/phenomena

Source: prepared by the authors, based on the research findings.

wealth and increase of social inequalities, and between development of motorization and environmental protection. The remaining contradictions were not as obvious, and were perceived only by some entrepreneurs and representatives of gmina authorities. They mainly pertained to the conflict between large-area, intensive agricultural production and environmental protection, and (only in the opinion of the entrepreneurs) between construction of roads and environmental protection. Only some concerns were expressed regarding the impact of urban development (suburbanization) and mass tourism on the condition of the natural environment. On the other hand, the influx of foreigners practically did not give rise to any controversy, which was most probably due to the minimal scale of this phenomenon.

\section{Application of Critical Trends and Thresholds to Regional Operational Programme (ROP) Ex Ante Evaluation}

In the second stage of its analyses, the research team applied the four-capital method and their trends/ thresholds for the purpose of evaluating the Structural Fund disbursement plans in 2007-2013. At first, the evaluation concerned the four capitals - their trends and thresholds in the Lubuskie voivodship, based on the stakeholders' opinions. Afterwards, conclusions that were drawn from the evaluation were compared with the ROP disbursements (Program Wojewódzki dla Województwa Lubuskiego na Lata $2005-2006,2005)$, in order to see to what extent ROP funding has been aligned with the identified critical trends and thresholds.

\section{Assessment of Critical Trends and Thresholds}

The aim of this part of the study was to assess the condition, as well as the expected changes, in the resources of the four capitals of the Lubuskie voivodship. The study method consisted of a workshop with the major stakeholders (about 20 persons - the Marshal of the Voivodship, directors of individual departments at the Marshal's Office, representatives of social partners and regional agencies of central institutions dealing with environmental protection, labour market and economic development). For the purpose of the workshop, individual capitals were expressed in terms of indices. Researchers limited their numbers to I8, based on the earlier experiences with panel discussions' animation (numbers of items to discuss higher than 20 made the discussion too vast and as result reduced group dynamics and the ability to make a conclusive assessment). During the discussion, the stakeholders made assessments of the successive indices: 
- direction of trends;

- current condition of a given process with respect to the critical threshold;

- personal (institutional) attitude towards the observed changes;

- political initiatives aimed at supporting the positive trend or changing the direction of a negative one.

The discussion on the condition of individual indices was structured and facilitated by experts and was, additionally, supplemented with the presentation of the evolution of the situation in the region (in the form of maps and statistical comparisons) against the background of the rest of the country and the EU, in various time frames. The stakeholders could therefore look back at the development of the Lubuskie voivodship from a wider perspective.

As far as the economic capital was concerned, the participants observed little involvement of local authorities and private companies in the area of the region's innovativeness. In a way, the lack of involvement has been translated into a general dissatisfaction with public initiatives aimed at ensuring economic development, as well as the increase of investment outlays, which, though growing, were still much lower than elsewhere in Poland. The low level of innovation in the voivodship resulted from the scarcity of adequately qualified personnel who could carry on research and development, which in turn resulted from a low percentage of people with higher education. Moreover, lack of some types of human capital was aggravated by insufficient involvement of the other types, evidenced by a low employment rate, which was considered close to critical. It went hand in hand with the deteriorating demographic structure and the ageing of the society, causing increased burden on the health care system, for a long time considered as failing anyway (below the critical threshold). At the same time, the spirit of entrepreneurship among the inhabitants willing to establish and run their own businesses was evaluated as high, which was seen as a sign of the influence of the instruments used by the authorities in support of the SME sector.

The low employment rate and high unemployment went hand in hand with high costs of social welfare; the clientele of the welfare system, however, remained at a stable level. The level of social mobilization, expressed as the inhabitants' participation in the activities of NGOs, was also evaluated as low, though stable. According to the authorities, success was achieved in combating petty and organized crime. As far as the natural capital was concerned, the predominant view was that matters were moving in the right direction and the amount of pollution was decreasing. The impact of the economic development and urbanization was evaluated as low and the area of the protected areas as high. Some dissatisfaction was expressed with the measures adopted by the public authorities with respect to retaining or decreasing the level of energy consumption, as in recent years its decrease was the result of resorting to simple solutions, like modernization, or of the collapse of industrial plants employing obsolete technologies.

To sum up, according to the stakeholders, the major areas of potential threats to a sustainable development of the region (critical thresholds exceeded or approached) included, first of all,

- low investment outlays in innovative activity;

- low level of employment in the R\&D sector;

- a failing health care system.

In view of the above, the initiatives of the local authorities financed under the ROP should be focused foremost on the solution of these problems.

\section{Regional Operational Programme (ROP) Financial Resources and Identified Challenges}

The other objective of the analysis was to check and compare to what extent the planned fund distribution corresponded to the earlier identified threats. For this purpose, critical points, i.e. problem areas revealed 
in the analysis of critical trends and thresholds and an earlier analysis concerning the updating of the Lubuskie Voivodship Development Strategy, were superimposed on the ROP priority and action tree.

The following main initiatives planned under the ROP were considered to promote the solution of the major problem areas (numbering corresponding to the original plan record).

(I.I) Improving regional transport infrastructure.

(I.2) Developing and modernizing educational infrastructure.

(I.4) Creating areas of economic activities.

(I.5) Developing information society.

(3.4) Promoting transfer of research, new technologies, innovations from research to business sector.

(4.2) Developing and improving local educational infrastructure.

(4.5) Developing the degraded urban and rural areas.

Subsequently, the expenditure structure broken down into priorities and activities (the amount of EUR and the percentage share of a given initiative in the ROP funding) was added to the picture. The funding was further broken down into four groups of activities: (a) above $7 \%$ of the ROP resources; (b) from 5 to $7 \%$; (c) from 3 to $5 \%$ and (d) below $3 \%$ of the planned expenditures. The resulting comparison shows that abundant resources were allocated to some of the problem areas, such as improving regional transport infrastructure and promoting transfer of research, new technologies, innovations from research to business, whereas three areas identified as problem areas were found in a group with the most insufficient funding. Thus, it is feared that the potential impact of the planned activities will prove inadequate. These areas included creating areas of economic activities, developing an information society and developing and improving local educational infrastructure. At the same time, some problems, due mainly to insufficient trade-off identification, were omitted at a regional operational programme level. They included, among others, the conflict of interests between large-scale agricultural production and environmental quality.

Based on the above conclusions, three major questions for the workshop discussions were formulated.

- Does the planned EU fund distribution in the region (under the ROP) correspond to the evaluation of the current condition and trends of the four capitals, including their position with respect to the identified critical thresholds?

- Is it possible to introduce changes to the resource allocation, based on conclusions drawn from the earlier stage of the analysis?

- Are there any potential trade-offs between ROP priorities?

As a result of the discussion, the stakeholders agreed to introduce changes in the tentative ROP fund allocation and to review the detected inconsistencies, in order to make the changes correspond to the results of the analysis of the four-capital model. The intended shifts of resources were primarily focused on the three major problems mentioned above. Moreover, the analysis revealed an ambiguous character (local or regional) of the activity related to the development of the degraded urban and rural areas.

It was also possible to identify and discuss trade-offs between investing in economic capital (support of companies, infrastructure) - ensuring quick, spectacular results - and investing in the human (education, schools) and the social capital (development of NGOs, networking) - which is a long-term and less spectacular activity, yet providing grounds for sustainable development. It was decided to involve, on a much broader scale, social partners in the process of strategy planning and to provide a financing line for small, local social mobilization projects.

At a later research stage, a detailed scrutiny of the omitted trade-off between economic and natural capital was planned. It was decided that the matter should be listed on the agenda of future workshops 
on the use of critical trends and workshops. The example that was provided concerned a potential negative impact of the heavily industrialized agriculture on the quality of environment on the local and regional scales.

\section{Conclusions and Recommendations}

When we compare the status of the individual types of capital in the Lubuskie voivodship with the average data of Poland and the European Union (Table I), we notice that the region has a distinct deficiency of manufactured and human capital. Apart from a low GDP level, the region still suffers from an acute shortage of basic technical and municipal infrastructure. There is a similar situation as regards human and social capital, the quality of which is lower than the average in both Poland and the EU. On the other hand, the condition of natural capital can be regarded as good or even very good, which is mainly due to a high share of woodland and a low population density in the region.

One can conclude from this exercise with the four-capital model that the regional authorities focus mainly on the development of manufactured capital. It seems that economic growth is the major goal, which governs all other objectives relating to the development of human capital, and - to a lesser extent - the development of social and natural capital. At its simplest, it can be said that in the case of the Lubuskie voivodship, where the level of economic development is low, the economic growth can exert a positive influence on the stock of the other capitals by improving the level of the residents' education, stimulating the growth of SMEs and raising environmental awareness.

As regards the implementation, tasks related to the development of manufactured and human capital are performed most efficiently, while those related to social capital do not meet expectations. This view is also shared by the local authorities and business people.

The existing environmental legislation is not perceived as hampering the development of the region, especially in view of the underdeveloped infrastructure and, to a lesser extent, the low level of innovation and a low quality of life of its residents. This is not a result of a low environmental awareness, which in fact happens to be quite high both among the entrepreneurs and among the representatives of the local authorities. The respondents were ready to incur additional costs related to environmental protection and biodiversity (however, there were controversies around big polluters who are harmful to the environment, yet at the same time provide employment to a large number of local people). Moreover, the assessment of operational objectives within the development strategy leads to the conclusion that the implementation of the majority of tasks will have a positive or neutral impact on natural capital. However, among conflicts emerging in the region, one can point out the conflict between large-scale agricultural production, the food-processing industry (especially meat processing) and environmental quality. Yet, this is a rather marginal issue in comparison with the view shared by a majority of the respondents that the increase of people's affluence leads to increased social inequality.

Based on the workshops and additional survey performed among representatives of local authorities and business, one can see the need for a revised strategy with more emphasis on the following, coupled with more efficient implementation of tasks relating to the following:

- development and implementation of a support system for businesses to help innovation and technology transfer;

- upgrade of the transport system respecting environmental requirements as well as improvement of alternative forms of road transport;

- ensuring equal access to education for children and youth and general improvement of the quality of the system; 
- diversification of farm business in rural areas, including the development of organic farming and reorientation of the monocultural farming system of large industrialized complexes;

- revitalization and strengthening of urban centres to minimize the adverse impact of suburbanization processes.

Sustainable development of the region seems to depend on successful implementation of the above objectives, and these should be incorporated in the 2007-2013 regional operational programme.

The performance of the above mentioned exercises has helped in reaching conclusions concerning the application of critical trends and thresholds and the four-capital model to the ex ante evaluation.

The tested method has proved to be a good instrument for evaluation of the regional development strategy and programme, and in particular their

- external coherence - alignment with other key strategic documents and the general plan for regional development;

- internal coherence - consistency between the goals and activities within the analysed document;

- relevance - to what extent the objectives of a programme correspond to the identified needs and whether they address the major strengths and weaknesses of a given context.

This is an interactive method as it relies on consultations. It obviously stimulated the stakeholders who joined the discussion and thus helped to build up their identification with the developed plans as well as their sense of ownership. The method fits the new model of evaluation by emphasizing the need to include the stakeholders in the process and, most of all, the evaluation itself (the so-called participative approach). Such an approach ensures a quick transition from the conclusions from evaluation to decision process - i.e. changes in the programme.

The tested method turned out to be very useful in showing the stakeholders a different, wider perspective of the programme and in increasing their understanding of the idea of sustainable development.

Technically, structuring the exchange of ideas around the four capitals has proved to be an effective and clear method of group discussion, document review and group decision making based on a compromise.

However, the application of a critical trend and threshold method carries certain requirements and restrictions. First of all, this is a prospective method used for evaluation of the structure of planned (prospective) documents. Were it to be applied to evaluate the effects of strategies that are currently implemented, it would require further modifications in combination with other evaluation methods (evaluation by beneficiaries, panel discussion of experts, analysis of regional data). In the second case, such an evaluation rather reflects the perception of the stakeholders.

Based on the observation from the workshops, it has to be noted that the application of the concept of critical trends and thresholds requires the following:

- elaborating a clear relation between the four capitals and between indicators of specific capitals and goals and actions of the strategic and programme documentation under evaluation;

- restricting the number of indicators and subjects to be discussed (up to 20);

- application of a clear and transparent evaluation system (preferably in some kind of graphic form) so that the final evaluation is easy to interpret by the participants of the panel discussion;

- combining with a good and competent animation of the discussion (including the presentation of contextual and comparative materials that would show the situation in a given region within the national or European context).

The survey showed that the stakeholders have problems with unequivocal assessment of critical trends and thresholds in all the capitals except the natural capital. The assessment seems to be relative and the critical point depends on the understanding of individual actors. 
Summing up, the applied tools seem to be useful in the evaluation of the regional development strategy and operational programmes of the EU Structural Funds.

\section{Documents}

Narodowa Strategia Rozwoju Regionalnego i Lokalnego 2001-2006 i 2007-2013 - Założenia. Ministerstwo Rozwoju Regionalnego: Warszawa.

Narodowy Plan Rozwoju 2004-2006 i 2007-2013. Ministerstwo Gospodarki: Warszawa.

Polityka Ekologiczna Państwa na Lata 2003-2006 z Uwzględnieniem Perspektywy na Lata 2007-2010. 2002. Ministerstwo Środowiska: Warszawa.

Prawo Ochrony Środowiska, Ustawa z dnia 27 kwietnia 200 I r. (Dz. U. Nr 62, poz. 627).

Program Ochrony Środowiska dla Województwa Lubuskiego na Lata 2003-2010. 2003. Zarząd Wojewódzki, Zielona Góra.

Program Wojewódzki dla Województwa Lubuskiego na Lata 2005-2006. 2005. Zarząd Wojewódzki, Zielona Góra.

Strategia Rozwoju Województwa Lubuskiego. 2000. Zarząd Województwa, Zielona Góra.

\section{References}

Gorzelak G, Jałowiecki B. 200I, Strategie Rozwoju Regionalnego Województw: Próba Oceny, Kwartalnik Studia Regionalne i Lokalne, Wyd. Naukowe SCHOLAR - EUROREG, No. I(5), S. 4I-59.

Parteka T. I997. Planowanie Strategiczne Rozwoju Zrównoważonego, Wydawnictwa Uniwersytetu Gdańskiego, Gdańsk.

Serageldin I, Steer A. I994. Epilogue: expanding the capital stock. In Making Development Sustainable: From Concepts to Action, Environmentally Sustainable Development Occasional Paper Series No. 2, Serageldin I, Steer A (eds). World Bank: Washington, DC.

Wilkin J. 2003. Ekonomia dla Prawników i nie Tylko. Wydawnictwo prawnicze LexisNexis: Warszawa.

World Bank. I995. Monitoring Environmental Progress (MEP); a Report on Work in Progress. World Bank: Washington, DC.

Żylicz T. 2004, Ekonomia Środowiska i Zasobów Naturalnych. Polskie Wydawnictwo Ekonomiczne: Warszawa. 